\title{
Study on Modern Environmental Art Design under Ecological Civilization Zhifeng Zhang ${ }^{1, \text { a }}$ \\ ${ }^{1}$ Planning and Design College of Xinyang Agricultural and Forestry University, Xinyang, Henan Province, 464000 \\ a email
}

Keywords: Modern Environmental Art Design, Ecological Civilization, Social Harmony

\begin{abstract}
Art and design development of modern society is in the development of socialist modernization, and human civilization has been further development. It makes environmental art design began to receive attention and concern, and its increasingly prominent in the development of the arts has unique design value. In the development of art and design, environmental art design includes all the range of human activities in space and environmental design elements, such as indoor and outdoor environmental design of human life. Because environmental art designers with Human activity space there is a relationship between art and design, so it has a very close contact with the human consciousness and values.
\end{abstract}

\section{Introduction}

Ecological civilization from the concept of sustainable development, policy guidelines ecological civilization by our congress report summary to specific performance and implementation of the concept of ecological civilization is to establish ecological "green" sustainable development of the whole society's values and the concept of development is the rise of ecological and sustainable development to a new level of social civilization, its meaning mainly contains the meaning of the following five aspects. The concept of ecological civilization requires production and development as much as possible to save energy and resources, improve the efficiency of energy utilization and recycling of resources to make use of renewable energy, actively develop non-renewable energy alternatives to satisfy the interests of the present and future generations of people use it. The concept of ecological civilization requires make production and development possibly strictly control emissions of major pollutants and emissions, the surrounding environment to minimize atmospheric "water" soil "climate pollution and destruction, carried out long-term thinking for present and future generations of healthy living. Ecological civilization requires business and society to improve as much as possible through a number of biotechnology or other technical means and the repair has been pollution and destruction of the environment, in order to point, and gradually transition to the ecological environment comprehensive improvement and repair. Ecological civilization stringent requirements as much as possible to protect existing healthy ecological environment through a dual mechanism national administrative law and social supervision from pollution and destruction, for any reason stop pollution "in any way and destroy. Ecological civilization requires as much as possible in society-wide publicity and promotion, the implementation of each of the units, "each family, establish a universal concept of ecological civilization, to promote environmentally friendly energy from the start, and gradually form a unitary consciousness and behavior of society as a whole, for the whole society and the whole world to contribute to sustainable development.

\section{The Request of Environmental Art Design under Ecological Civilization}

As people's material living standards rising, people began to develop a more demanding began to form the idea of human life and the environment are closely related to ecological civilization, this concept is a dynamic ideology and with the times and social development the change, but also because this subtle concept of ecological civilization subjectivity of people's production and life has brought significant influence. Therefore, this concept of ecological civilization is the product of a 
scientific concept of development, its core is about the ecological values and the development and extension. So on the basis of the current rapid economic development, we must pay attention to the ecological values of the deepening and optimization to make the necessary actions to reduce pollution and environmental impact on human life. With the rapid development of China's first industry, environmental pollution on the rise, people have higher requirements for environmental requirements and pay more attention to the pursuit of nature, so the environmental art design, designers must strengthen the integration of regression in the design important natural philosophy, and by effectively increasing the original ecological approach to people with the desired contact between nature more closely; ecological view of life at the same time pay attention to the requirements of transmitting cultural connotations, and focus on using innovative ideas to enhance the diversification Thought integration, combined with local specialties regional environment will be combined elements of traditional culture, humanistic and artistry to achieve harmonization of ecological civilization.

Environmental Art and Design is a comprehensive art is very strong. Environmental soul of art including the "King" and "love", natural scenery and cultural landscape is the "King" of the expression form. Environmental art is basically to art as a framework, the use of building carrier performance. Environmental art design to try to maintain the harmonious development between man and nature and ecological balance, and promote harmony between man and nature is the ultimate principle of environmental art design, designers follow this principle, we will be able to ensure that people comply with environmental art and design in nature aesthetic ideas. Thus conceivable, environmental design and ecological civilization are inextricably related.

\section{Modern Ecological Civilization Art and Design}

Interior Design Art. Human thought in progress, the rapid development of science and technology in the past, building model has been unable to meet the required interior design now, but also behind the ideology of ecological civilization now. Therefore, in order to establish a good indoor space environment, designers must establish ecological model adaptation based on the current environmental art design needs. First of all, to examine the construction site of the natural environment is characterized by the principle of combining architecture and ecology through the latest technology approach, all factors that affect the building and around the building are unified, rational planning, the building with the surrounding environment together organically, try to make the internal condition of the building has an ability to regulate in order to allow people living environment requirements are met. For example, you can use solar energy and other renewable energy sources, but also the application of new brick to prevent heat and sound penetration. Secondly, in the present art design, you can reduce the use of non-clay brick extent of the damage to the soil, effective application of ecological construction model, in order to maintain a good indoor environment and provide more interior demand conditions are met, namely simplified as far as possible to ensure that create comfortable indoor environment on the basis of interior decoration procedures, reduce pollution and damage to the environment caused by the renovation.

Today, interior design of environment rational use air to the environment, to create a good natural light and other indoor ecological space. In the renovation process can be applied to eco-friendly materials, make sure it is healthy for the environment of space. Making the actual interior design, it is possible to make the best use of green plants, green plants can purify the air, and put breath in space becomes more natural. The introduction of natural light through its interior toward the surface of the transparent glass windows and architecture, try to make indoor air circulation smoothly, will be discharged in indoor emissions. At the same time, in today's interior decoration, it should prohibit the use of environmentally friendly low coefficient of substandard paint or plywood and other decorative materials, more use of some natural materials such as bamboo, rattan, and some products and materials can be recycled as far as possible selection suitable heating articles and lighting objects, avoid wasting resources, reducing pollution caused by waste materials. Previous interior design and decoration material often used in the form of a pile, indoor environmental space is designed to be cumbersome and complex. However, most previous 
designs and much sought simple, generous, decent aesthetics do not match. In the past, some of the decoration, the aspect of waste a considerable amount of natural resources, paint and plywood on the other hand will be used in a number of volatile toxic gases, serious harm to people's health. Therefore, the modern environmental design should be simple, generous, decent design, reasonable handling materials, focusing on design details in order to meet people's aesthetic ideas and the concept of environmental protection.

Design of Outdoor Arts. Now, the outdoor environment is the most important art and design landscape design. During the landscape design should be rational planning in the form of the landscape, avoiding the cost of the budget is too big, too much energy consumption, volume of heavy weight and other issues. For example, the high cost should not be used when designing the fountain, an area of large fountain design, should be based on the flow of people in different places, the area occupied by the rational design of fountains and other factors, so that water and electricity, land and other resources have been reasonable use, thereby reduce waste of resources. During the outdoor design, respond land, natural environment, rational design. Urban environment can not be separated "lung" - green. Green can be more natural for people to create a good environment and comfortable living space, the surrounding climate, the environment will have a slight adjustment. Therefore, the designer of the city planning and construction should be rational use of extra space around the building, the construction of a better green environment. When carrying out the specific landscape designer space design, should make better use of the landscape, plants, etc., so that the landscape composition in the form of more beautiful and practical, showing the natural and ecological elements of the design, so that people can better get close to nature.

Designer outdoor environmental art design process, we must not destroy the original ecological environment, should not damage the surrounding environment of the original features, should make full use of existing natural conditions, to avoid large-scale transformation, as much as possible in the original the design on the natural resource base. In the process of building, it should vegetation, soil and other natural ecological terrain to be protected against damage to the local micro-climate and food chain. In the design of the ecological environment, the ecological balance as you want to focus, combined with the local natural factors implementation of the transformation, so that we can try to avoid the destruction of the natural landscape. At the same time, we should not undermine the basis of the original ecological balance, planting more green vegetation, increase the green area.

Environmental art design to keep up the pace of development of the concept of ecological civilization, the theory and methods of science, and strictly abide by the following principles: Today, thanks to advances in science and technology and industrial development, people enjoying the modernization of superior living environment people fast-paced lifestyle and socio-cultural imbalances have been highlighted in the course material civilization highly developed. At the same time, it is difficult to avoid the hazards of environmental pollution and ecological damage to the environment arising. In the context of ecological civilization, it is environmental protection awareness so that people return to nature the idea more strongly. Therefore, environmental art designers want to encourage people to return to natural efforts, the application of some design methods to get people from the body and the spirit return to nature. Designers emotions hidden in the works of design, so we can learn from some of the works of environmental art design designer feel care for the environment, care for the feelings of humanity. However, some designers too much emphasis on the environment in the form of artistic expression, while ignoring the ecological and cultural spirit, some environmental art and design appears innovative enough, the lack of characteristic problems. Designers should pay attention to the spirit of cultural and ecological environment art design, increase the aesthetics of learning and understanding, improve their aesthetics, use a variety of ideological and cultural spirit to achieve ecological environment art design, while improving their artistic creativity, so that their work in line with the requirements of the audience and industrial design. Make different social spirit of the application of different environmental performance space, the beauty of art and design of the environment to be fully reflected, so that everyone can understand the true, good and beautiful realm of art. 


\section{Conclusion}

Under the guidance of the concept of ecological civilization, '\$ harmony became the overall development direction of modern environmental art design. Harmony, harmony is not only small between people, it is great harmony between man and nature, only to achieve a great harmony , in order to continuously improve the human environment, society can be truly sustainable development. Environmental Art and design is just one way the relationship between the contact with nature, people's living environment and the natural environment can be coordinated through it. modern environment Art and design is to change the past in order to destroy people's living environment and the natural environment of the practice, but people's living environment should meet the requirements under the premise of protecting the natural environment, to achieve great harmony between man and nature.

\section{References}

[1] Fu Haobin. Modern Art Design Environment under ecological civilization [J]. Intellect, 2013 (13).

[2] Liu Yujuan. Ecological Civilization and Art and Design [J]. Reading Digest, 2015 (02).

[3] Limei Hong. Modern Art Design Environment under ecological civilization [J]. Art Education Research, 2013 (16).

[4] Rossi. Ecological environmental design concept and its aesthetic characteristics [J]. Art and Science, 2014 (11).

[5] Li Meihong. Modern Art Design Environment under ecological civilization [J]. Art Education Research, 2013 (16).

河南省信阳市平桥区北环路 1 号（信阳农林学院规划与设计学院）收件人:张志锋手 机:13673086559 